earlier literature; the term "angina pectoris saturnina" was used by Hirschfeld (1926) in reporting cases of lead poisoning. More recently electrocardiographic changes have been reported in association with chest pain in cases of lead poisoning (Kosmider and Petelenz, 1961), and in a series of five fatal cases in children myocardial lesions-a subacute interstitial myocarditis-were thought to be responsible for the deaths of two and to have contributed to the death of the other three (Kline, 1960). Henderson and Inglis (1957) drew attention to high bone lead concentrations and a history of plumbism in childhood in a series of fatal cases of renal failure with hypertension-mainly young adults. Dingwall-Fordyce and Lane (1963) found more deaths from cerebrovascular disease in lead workers than in a control population.

We cannot say whether the absorption of lead from drinking water has been a factor in producing the differences in cardiovascular mortality between soft and hard water areas and, if so, how big a factor. It clearly does not "explain" the whole association between mortality and the softness of drinking water, but, as stated previously (Crawford et al., 1971), it could be an important contributory factor enhancing the correlations and causing the clearer picture found in Britain than in other countries.

As already stated, very effective corrective measures have been applied over a long period of time to many water supplies in England and Wales which would otherwise have been plumbosolvent; and there is some evidence in our studies of the county boroughs that some soft water towns, where effective treatment with lime has been applied for many years, have lower death rates than would be expected. In some supplies treatment to raise $\mathrm{pH}$ has started more recently and we are following the death rates in these towns. It is important that there is continued monitoring of supplies because of the great variability from house to house and from day to day in the same supply.

There is need for studies of possible mechanisms of how the lead ion may be operating in cardiovascular disease-for example, does the lead ion replace calcium or magnesium in vital electrochemical combinations or interfere in specific enzyme systems in the heart muscle ? If its role can be better identified it might yield important clues to aetiology of cardiovascular diseases.

A grant from the World Health Organization contributed to the cost of the analyses.

We wish to thank the medical officers of health of the study towns and their staffs for much help in organizing the study and in collecting samples; Dr. A. A. Smales, of the analytical division of the Atomic Energy Research Establishment, and his staff for the bone analyses; Dr. R. C. Hoather, of the Counties Public Health Laboratories, and his staff for the water analyses; and our colleagues and the staff of the M.R.C. Social Medicine Unit, in particular Mrs. D. Greystoke.

\section{References}

Beattie, A. D., Moore, M. R., Deveney, W. T., Miller, A. R., and Goldberg, A. (1972). British Medical fournal 2 491.

Crawford, M. D., and Crawford, T. (1969). Lancet, 2, 699.

Crawford, M. D., Gardner, M. J., and Morris, J. N. (1971). British Medical Bulletin, 27, 21 .

Crawford, M. D., and Morris, J. N. (1967). Lancet, 2, 1087.

Crawford, T., and Crawford, M. D. (1967). Lancet, 1, 229.

Dingwall-Fordyce, I., and Lane, R. E. (1963). British fournal of Industrial Medicine, 20, 313 .

Henderson, D. A., and Inglis, J. A. (1957). Australasian Annals of Medicine, 6,145 .

Hirschfeld, E. (1926). Zeitschrift für klinische Medizin, 104, 698.

Kline, T. S. (1960). American fournal of Diseases of Childhood, 99, 48.

Kosmider, S., and Petelenz, T. (1961). Polskie Archiwum Medycyny Wewnetrznej, 31, 1349.

Hislop, J. S., Parker, A., Spicer, G. S., and Webb, M. S. W. (1973). Atomic Energy Research Establishment Report No. 7321. London, H.M.S.O.

Millar, J. A., Battistini, V., Cumming, R. L. C., Carswell, F., and Goldberg A. (1970). Lancet, 2, 695 .

Reed, C. D., and Tolley, J. A. (1971). Journal of the Royal College of General Practitioners, 21, 289 .

Schroeder, H. A. (1965). Fournal of Chronic Diseases, 18, 217.

Six, K. M., and Goyer, R. A. (1970). Fournal of Laboratory and Clinical Medicine, 76, 933.

Stitt, F. W., Clayton, D. G., Crawford, M. D., and Morris, J. N. (1973) Lancet, 1,122

Wilson, A. T. (1966). Practitioner, 197, 77.

Wilson, A. T. (1967). Lancet, 1, 956.

World Health Organization (1971). International Standards for Drinking Water, Geneva, W.H.O.

\title{
Hypoxic Changes in Conducting Tissue of the Heart in Sudden Death in Infancy Syndrome
}

\author{
JAMES A. J. FERRIS
}

\begin{abstract}
Introduction
During the past 15 years much research has been devoted to the clinical entity now known as the "sudden death in infancy syndrome" ("cot death" or "crib death"). Recent efforts have been made to correlate the wide variety of aetiological theories (Bergman et al., 1970; Camps and Carpenter, 1972); the final mechanism of death, however, remains as yet unestablished. The present study reports the discovery of petechial haemorrhages in the region of the sinus node and the conducting tissue tracts leading to the atrioventricular node in a series of 11 sudden unexpected infant deaths.
\end{abstract}

\section{Materials and Methods}

Fifty cases of sudden death in infancy have been investigated so far. Only patients with a clinical history of sudden unexpected death in whom no precise cause could be found at necropsy were included. Because of the need to supply a cause of death to the coroner before full histological, bacteriological, and virus
Department of Pathology, University of Newcastle upon Tyne, Royal Victoria Infirmary, Newcastle upon Tyne NE1 4LP JAMES A. J. FERRIS, M.D., D.M.J., Lecturer in Forensic Pathology 
studies could be completed, this initial selection was made on gross necropsy appearances only.

Tissue from all organs, including three representative sections from each lung, was taken for routine histological examination. The hearts were fixed in formol saline, as far as possible intact. They were then hand processed and serially sectioned along the line of the interventricular septum. A modification of this serial sectioning is now applied with five sections being taken on 0.5$\mathrm{mm}$ levels through the heart. This reduces the number of sections obtained from over 1,500 to about 150 . One section from each level is stained with haematoxylin and eosin and special stains are applied to the "blanks" as required. This procedure permits careful examination of the whole of both atria and it is possible to identify the sinus node and what appear to be its communications with the atrioventricular node and His's bundle.

\section{Results}

Histological examination of the lungs in 17 cases showed changes characteristic of either acute brochiolitis or viral pneumonitis. In all of these cases there was acute inflammatory infiltration around the small bronchi and in several cases there was superimposed bronchopneumonia. A relatively high incidence of viruses, mostly respiratory syncytial virus or one of the influenza viruses were identified, and these results will be published shortly (Gardner et al., 1973). One case was found to have a florid myocarditis but no virus was cultured.

Of the remaining 32 cases the histological changes in the lungs were essentially similar. There were varying degrees of congestion, oedema, patchy collapse, and a diffuse increase in alveolar wall cellularity. In none of these cases was there any evidence of acute bronchiolitis or pneumonia, and virology was negative. There was no disease present in any other organ of the body.

Histological examination of serial sections through the hearts showed the presence of petechial haemorrhages in the wall of the right atrium in 11 cases and in five of these haemorrhages were present either closely related to or within the tissue of the sinus node. These haemorrhages varied in size and were almost exclusively confined to the muscle of the right atrium. The distribution of haemorrhages in the atrial wall is given in the table. Some were very large (fig. 1) and seemed to lie within the

Sites of Petechial Haemorrhage Within the Right Atrial Muscle in 11 Cases of Sudden Death in Infancy Syndrome

\begin{tabular}{|c|c|c|c|c|c|c|}
\hline & \multirow{2}{*}{\multicolumn{2}{|c|}{ Case No. }} & \multirow{2}{*}{ Sex } & \multirow{2}{*}{ Age } & \multicolumn{2}{|c|}{ Sites of Cardiac Haemorrhage } \\
\hline & & & & & Sinus Node & Atrial Wall \\
\hline $\begin{array}{r}1 \\
2 \\
3 \\
4 \\
5 \\
6 \\
7 \\
8 \\
9 \\
10 \\
11\end{array}$ & $\begin{array}{l}\because \\
\because \\
\because \\
\because \\
\because \\
\because \\
\because \\
\end{array}$ & $\begin{array}{l}\because \\
\because \\
\because \\
\because \\
\because \\
\because \\
\because \\
\end{array}$ & $\begin{array}{l}\text { M. } \\
\text { M. } \\
\text { M. } \\
\mathbf{F} . \\
\text { F. } \\
\text { M. } \\
\text { M. } \\
\text { F. } \\
\text { M. } \\
\text { M. } \\
\text { F. }\end{array}$ & $\begin{array}{l}3 \text { months } \\
9 \text { weeks } \\
8 \text { weeks } \\
5 \text { months } \\
4 \text { months } \\
9 \text { weeks } \\
5 \text { months } \\
3 \text { months } \\
10 \text { weeks } \\
8 \text { weeks } \\
3 \text { weeks }\end{array}$ & $\begin{array}{l} \pm \\
\pm \\
\pm \\
\pm \\
\pm \\
\pm \\
+\end{array}$ & $\begin{array}{l}+ \\
+ \\
+ \\
+ \\
+ \\
+ \\
+ \\
+ \\
+ \\
+ \\
+\end{array}$ \\
\hline
\end{tabular}

bundles of fibres thought by James (1963) to be part of the internodal communicating tracts. In one instance (case 10, fig. 2) there was a haemorrhage at a level just above the atrioventricular node and it was possible to identify conducting tissue fibres passing through the area of haemorrhage into the nodal tissue. Case 11 was unusual. This child had hydrocephalus associated with a meningocele and had been treated with a Spitz-Holter valve. She was found dead unexpectedly in her cot and at necropsy there were multiple petechial haemorrhages on the surface of both lungs, on the thymus, and on the epicardial surface of the heart. It was thought that the neurological

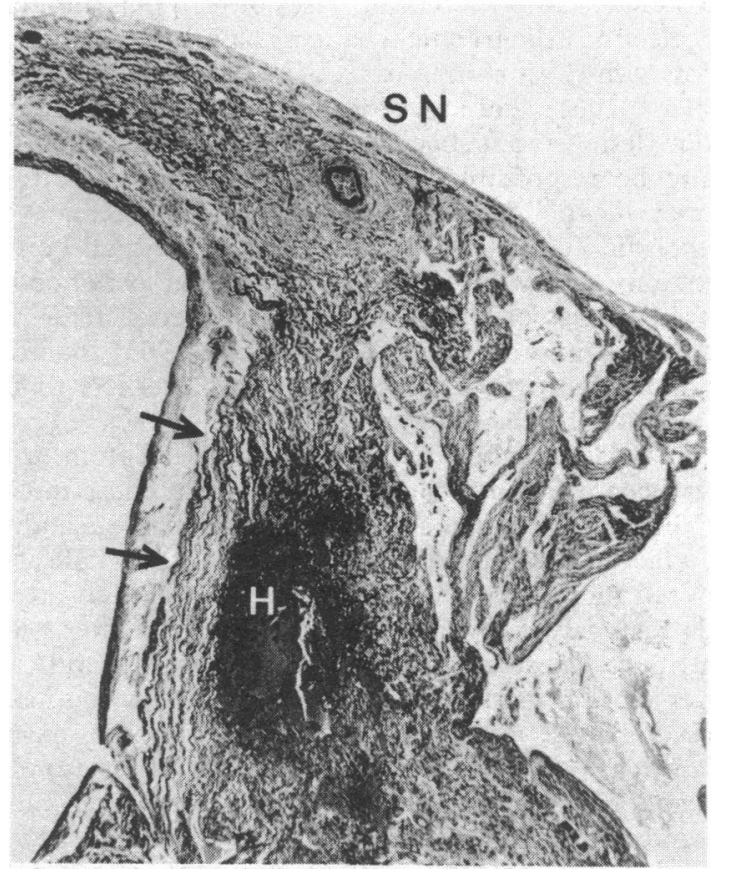

FIG. 1-Section through right atrial wall in case 5 showing haemorrhagic distribution (H) of the internodal tracts (arrowed). The sinus node (SN) in this case was apparently normal. (Haematoxylin and eosin. $\times 23$.)

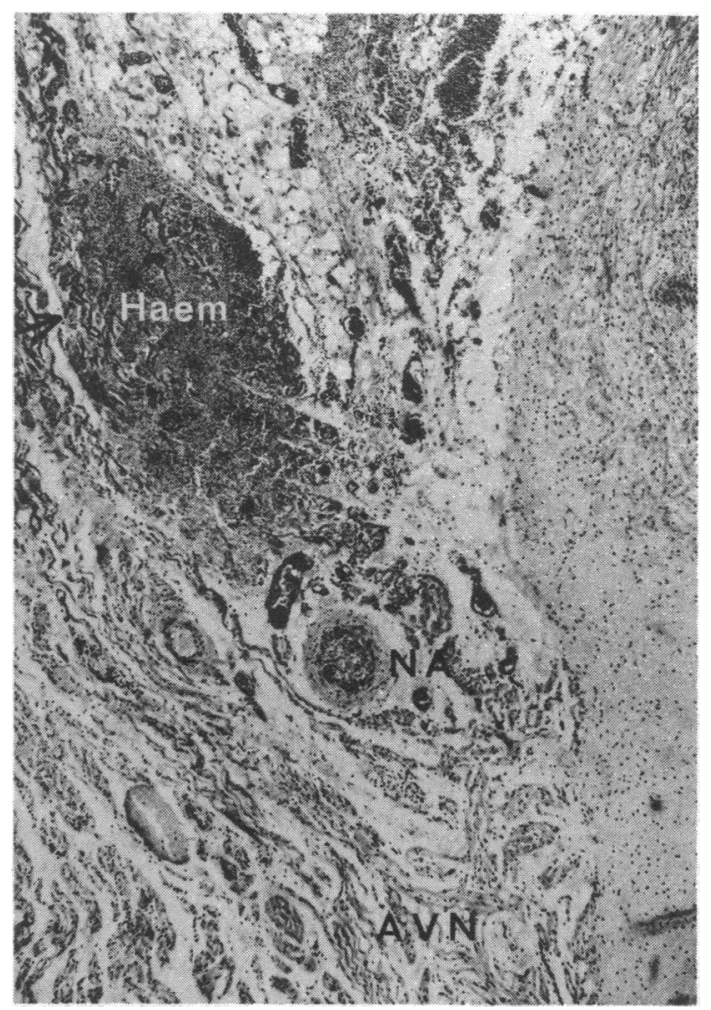

FIG. 2-Case 10 showing haemorrhage (Haem) at a level just above atrioventricular node (AVN). Internodal communicating tracts (arrowed) can be seen within area of haemorrhage. A.V. nodal artery (NA) was normal. (Haematoxylin and eosin. $\times 115$.)

abnormalities played no part in her death and that she was a true case of sudden death in infancy.

In none of the bronchiolitis group of cases have similar haemorrhages within the conducting tissue structures been identified. 


\section{Discussion}

It is generally accepted that in the "sudden death infancy syndrome" the infants have been healthy during life and they die because of some critical combination of environmental and intrinsic factors, either by a respiratory mechanism (Bergman et al., 1970; Shaw, 1970), a lethal cardiac arrythmia or conduction disturbance (James, 1968; Ferris, 1972), or a hypersensitivity reaction to antigens, at present unidentified but thought to be in cows' milk protein (Parish et al., 1960).

One of the major difficulties has been to relate the dramatic unexpected suddenness of death to the apparently minor changes seen at necropsy. A feature which is present at necropsy in most cases is intrathoracic, multiple petechial haemorrhages almost entirely confined to the thymus, the surface of the pleurae, and the epicardium-particularly in the atrioventricular groove. The possible aetiological importance of these haemorrhages was stressed by Bergman et al. (1970). Traditionally, petechial haemorrhages are attributed to asphyxial deaths, but as Teare and Knight (1971) pointed out such haemorrhages are commonly seen in cases where no asphyxia or suffocation has occurred, and they stressed that under no circumstances must the presence of such petechiae be interpreted as indicating an unnatural death. Because of a fear of incorrect interpretation of these petechial haemorrhages their significance in the sudden death in infancy syndrome has been minimized.

Lewis and Matheson (1910) experimentally produced heartblock by asphyxia and proved that it was hypoxia and not the accumulation of carbon dioxide that was responsible for the resultant dysrhythmias. Thung et al. (1962) as a result of both clinical and experimental evidence were able to show the importance of hypoxia as a cause of dysrhythmia. In a series of newborn infants who died of pulmonary insufficiency and patients who had been hypoxic before death it was found that the hypoxia was frequently associated with haemorrhages into the conducting system. Comparable haemorrhages with associated dysrhythmias were produced in experimental animals in a low oxygen atmosphere and it was concluded that these haemorrhages and the dysrhythmias were causally related. In a group of 10 out of 25 perinatal infant deaths similar conducting tissue haemorrhages were reported by Hoch-Ligeti and Diaz-Perez (1962). They considered these lesions to be significant factors in a failure to survive respiratory problems in the perinatal period.

The conducting system is one of the most heavily vascularized parts of the heart. Large thin wall venous sinuses can be easily seen and it is possible that hypoxia produces changes in the capillary walls, increasing permeability and thus predisposing to haemorrhage. Such haemorrhages may be further contributed to by a terminal congestive phase with a rise in venous pressure.

In the sudden death in infancy syndrome the problem in the past has been to rationalize the relatively trivial changes often reported in the lungs with the dramatic suddenness of death. Most of the current theories on the cause of death in these cases implicate respiratory distress either as a result of brochospasm associated with sensitivity to inhaled cows' milk protein (Camps, 1970) or to a respiratory infection (Bergman et al., 1970). It seems possible that, since such respiratory problems will be associated with varying degrees of hypoxia, fatal haemorrhages could occur in the conducting system by the mechanisms indicated. In all 11 cases reported here the haemorrhages were within recognizable conducting tissue structures and as such must be thought significant in the mechanism of death. It is possible that a predisposition to such haemorrhages may well account for a failure to survive in the sudden death in infancy syndrome and provide the important link between minimal observed pathological changes and sudden death.

I am indebted to Dr. W. A. Aherne for the provision of several cases, to Professor A. G. Heppleston for his continuing encouragement and advice in this work, and to Mr. J. Maclennan and Mr. A. E. Young for their technical and photographic expertise.

\section{References}

Bergman, A. B., Beckwith, J. B., and Ray, C. G. (1970). Sudden Infant Death Syndrome. Seattle, University of Washington Press.

Camps, F. E. (1970). British fournal of Hospital Medicine, 4, 779.

Camps, F. E., and Carpenter, R. G. (1972). Sudden and Unexpected Deaths in Infancy. Bristol, John Wright.

Ferris, J. A. J. (1972). Medicine, Science and the Law, 12, 173.

Gardner, P., Ferris, J. A. J., and Aherne, W. A. (1973). In preparation.

Hoch-Ligeti, C., and Diaz-Perez, R. (1962). American fournal of Obstetrics and Gynecology, 84, 804.

James, T. N. (1963). American Heart fournal, 66, 498

James, T. N. (1968). American fournal of Cardiology, 22, 479.

Lewis, T., and Matheson, G. C. (1910). Heart, 2, 47.

Parish, W. E., Barrett, A. M., Coombs, R. R. A., Gunter, M., and Camps, F. E. (1960). Lancet, 2, 1106

Shaw, E. B. (1970). American fournal of Diseases of Childhood, 119, 416. Teare, D., and Knight, T. (1971). Science fournal, January, p. 71.

Thung, N., et al. (1962). Fournal of Thoracic and Cardiovascular Surgery, 44,687 .

\section{Automatic Transmission Vehicle Injuries}

\section{MALCOLM FIDLER}

British Medical fournal, 1973, 2, 25-26

\section{Summary}

Four drivers sustained severe injuries when run down by their own automatic cars while adjusting the carburettor or throttle linkages. The transmission had been left in the "Drive" position and the engine was idling. This accident is easily avoidable.

Royal National Orthopaedic Hospital, London W1N 6AD

MALCOLM FIDLER, F.R.C.s., Orthopaedic Registrar (At present Senior Orthopaedic Registrar, Whittington Hospital, London N19 5NF)

\section{Introduction}

During recent years considerable interest has been focused on the injuries associated with road traffic accidents, their mechanism, methods of treatment, and means of prevention. The following four case reports describe injuries sustained by drivers run down by their own vehicles. In each case the car had automatic transmission, the injury was severe, and could easily have been avoided. This type of accident has not previously been described.

\section{Case Reports}

Case 1.-A man aged 66 was admitted to University College Hospital in June 1964. He had been adjusting the carburettor of his Mercedes-Benz motor car with the engine idling, and although the vehicle was stationary the automatic transmission was in the drive position. He increased the engine speed by moving the 